\title{
Perbandingan Analytical Hierarchy Process dan Fuzzy Mamdani untuk Sistem Pendukung Keputusan Pemilihan Rumah di Daerah Cepu
}

\author{
Adhika Pramita Widyassari' ${ }^{1}$, Teguh Yuwono ${ }^{2}$ \\ ${ }^{1,2}$ STTR Cepu; Jl. Kampus Ronggolawe No.1, Mentul Indah Cepu, telp 0296422322 \\ 1,2 Jurusan Teknik Elektro, STTR Cepu, Blora \\ e-mail:1 1ika trunix@yahoo.com, ${ }^{2}$ ridalutfa@gmail.com
}

\begin{abstract}
Abstrak- Rumah merupakan kebutuhan dasar dan penting bagi semua manusia. Menyadari itu semua, banyak developer menawarkan berbagai alternative rumah dari mulai harga, lokasi, desain, fasilitas, maupun luas tanah. Hal inilah yang menyebabkan konsumen harus pandai-pandai memilih perumahan mana yang akan mereka ambil yang sesuai dengan kriteria-kriteria yang diinginkan. Sistem pendukung keputusan dibangun untuk membantu orang dalam menentukan pilihan dalam kasus ini adalah membantu orang untuk memilih perumahan yang diinginkan dari berbagai pilihan perumahan yang ada berdasarkan ke lima aspek tersebut. Sistem dengan metode AHP ini juga menjanjikan proses penilaian yang lebih baik karena dapat memberikan bobot kepada berbagai aspek penilaian. Fuzzy Mamdani berperan sebagai pendukung keputusan karena dalam dunia nyata pembeli sering kesulitan untuk memilih rumah idamannya dengan beberapa kriteria yang sesuai dengan kebutuhannya Kesimpulan dari penelitian ini adalah 1) AHP dan Fuzzy Mamdani dapat dijadikan sebagai analisis dalam sistem pendukung keputusan menentukan pilihan rumah. 2) Perbandingan AHP dengan Fuzzy Mamdani dengan kasus pemilihan rumah adalah 0,90298. 3) Tingkat akurasi AHP lebih baik dibandingkan dengan Fuzzy Mamdani pada kasus pemilihan rumah dengan MSE sebesar 0.048538
\end{abstract}

Kata kunci-sistem pendukung keputusan, pemilihan rumah, AHP, fuzzy Mamdani

\section{Pendahuluan}

Gejolak perkembangan di bidang properti ini tidak hanya dipengaruhi oleh membaiknya perekonomian tetapi juga minat para konsumen mengikuti perkembangan ini. Peningkatan jumlah konsumen dari tahun ke tahun semakin bertambah. Para developer banyak yang menawarkan berbagai alternatif dari mulai harga, lokasi, desain, maupun cara pembayaran. Dan pada umumnya di kawasan $\mathrm{Cepu,} \mathrm{rumah} \mathrm{yang}$ ditawarkan berbagai developer adalah rumah sangat sederhana (RSS), dimaksudkan untuk menarik minat konsumen dengan penghasilan ke bawah. Hal inilah yang menyebabkan konsumen harus pandai-pandai memilih perumahan mana yang akan mereka ambil yang sesuai dengan kriteria-kriteria yang diinginkan.

AHP merupakan sebuah hirarki fungsional dengan input utamanya persepsi manusia. Dengan hirarki, suatu masalah kompleks dan tidak tersruktur dipecahkan kedalam kelompok-kelompoknya, kemudian kelompokkelompok tersebut diatur menjadi suatu bentuk hirarki [1]. Tetapi AHP sulit untuk di analisa jika alternatif yang muncul terlalu banyak.

Logika fuzzy merupakan suatu cara yang tepat untuk memetakan suatu ruang input ke dalam suatu ruang output. Konsep logika fuzzy mudah dimengerti, karena logika fuzzy menggunakan dasar teori himpunan, maka konsep matematis yang mendasari penalaran fuzzy tersebut cukup mudah untuk dimengerti.

Untuk permasalahan pemilihan rumah, logika fuzzy berperan sebagai pendukung keputusan karena dalam dunia nyata pembeli sering kesulitan untuk memilih rumah idamannya dengan beberapa kriteria yang sesuai dengan kebutuhannya. Dengan logika fuzzy, kriteria ini dapat dibentuk menjadi data kualitatif dengan pengklasifikasian data (dapat digolongkan) yang pada kenyataannya lebih mudah dimengerti oleh pengguna. Setelah dilakukan pengklasifikasian, kemudian digunakan metode inferensi minimum, dalam penelitian ini menggunakan inferensi Mamdani yang bertujuan untuk mempertimbangkan antara beberapa alternatif pilihan yang memiliki nilai pertimbangan atau perangkingan yang paling tinggi untuk dipilih [2].

\section{LANDASAN TEORI}

AHP merupakan sebuah hirarki fungsional dengan input utamanya persepsi manusia. Dengan hirarki, suatu masalah kompleks dan tidak tersruktur dipecahkan kedalam kelompok-kelompoknya, kemudian kelompokkelompok tersebut diatur menjadi suatu bentuk hirarki [3]. Tetapi AHP sulit untuk di analisa jika alternatif yang muncul terlalu banyak.

AHP telah diteliti sebelumnya oleh Rini Artika dkk [4] dengan penelitiannya yang berjudul, Penerapan Analitycal Hierarchy Procces (AHP) Dalam Pendukung Keputusan Penilaian Kinerja Guru Pada SD Negeri 095224. AHP juga telah diteliti sebelumnya oleh Supriyono, $\mathrm{dkk}[5]$ yang meneliti tentang sistem pemilihan pejabat struktural dengan metode AHP. Kemudian penelitian yang berjudul "Perancangan Sistem Pendukung Keputusan Dan Sistem Informasi Geografis Pemberian Bantuan Korban Banjir Di Kabupaten Bandung Selatan" oleh Ayu Permata, dkk [6].

Penelitian pemilihan rumah menggunakan fuzzy pernah dilakukan oleh Angga Fitra yang berjudul 
Sistem Pendukung Keputusan Pemilihan Perumahan Dengan Metode Fuzzy Tahani. Penelitian ini menghasilkan aplikasi sistem pendukung keputusan pemilihan perumahan dengan fasilitas penyimpanan database secara terstruktur sebagai pendukung keputusan dalam pemilihan rumah yang di aplikasikan dengan Bahasa pemrograma Microsoft Visual Basic 6.0 dan MySql sebagai databasenya [7].

\section{METODE}

A. Pengumpulan data

Data yang dimaksud adalah data rumah, kriteria, rating yang diambil dengan cara observasi dan wawancara. Kriteria yang telah ditetapak ada 5 kriteria yaitu harga, lokasi, fasilitas, luas tanah, dan desain.

$B$. Perancangan.

Setelah data yang dibutuhkan terkumpul, maka dilakukan perancangan yang dimaksud adalah perancangan struktur hirarki pada metode AHP dan perancangan pada fuzzy. Struktur hirarki menggunakan AHP dan perancangan fungsi keanggotaan pada Fuzzy dijelaskan pada gambar 1 dan 2.

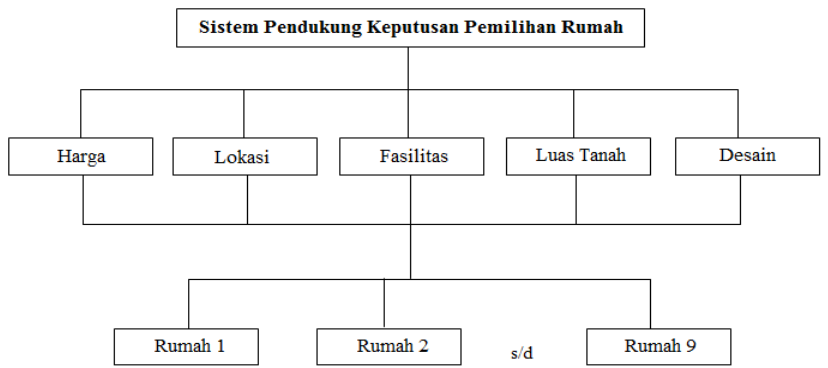

Gambar 1 Hirarki Pemilihan rumah dengan AHP

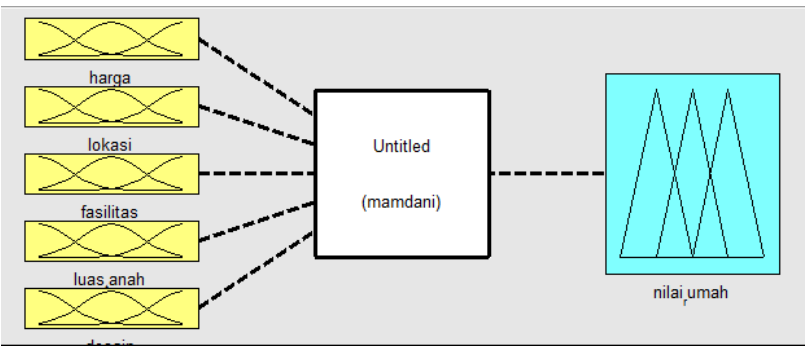

Gambar 2 Perancangan Pemilihan Rumah dengan Fuzzy Mamdani

C. Perhitungan

Perhitungan di dalam metode AHP adalah 1) menghitung matriks perbandian antara kriteria yang terlebih dahulu dilakukan skala nilai, 2) melakukan perhitungan prioritas kriteria, 3) menghitung konsistensi, 4) perhitungan bobot. Proses perhitungan dengan AHP pada langkah 1, 2, 3 dan 4 dijelaskan pada tabel 1,2, 3 dan 4 berikut ini:
Tabel 1 Matriks Perbandingan Berpasangan

\begin{tabular}{|l|r|r|r|r|r|}
\hline & \multicolumn{1}{|l|}{ Harga } & \multicolumn{1}{l|}{ lokasi } & \multicolumn{1}{l|}{ Fasilitas } & \multicolumn{1}{l}{ Luas } & \multicolumn{1}{l|}{ desain } \\
\hline Harga & 1 & 1 & 2 & 3 & 5 \\
\hline Lokasi & 1 & 1 & 0.5 & 3 & 3 \\
\hline Fasilitas & 0.5 & 2 & 1 & 3 & 5 \\
\hline Luas & 0.333 & 0.333 & 0.333 & 1 & 2 \\
\hline Desain & 0.2 & 0.333 & 0.2 & 0.5 & 1 \\
\hline Jml & 3.033 & 4.666 & 4.033 & 10.5 & 16 \\
\hline
\end{tabular}

Tabel 2 Perhitungan Prioritas Setiap Kriteria

\begin{tabular}{|l|r|r|r|l|r|r|r|}
\hline & Harga & Lokasi & Fasilitas & Luas & desain & jumlah & prioritas \\
\hline harga & 0.33 & 0.214 & 0.496 & 0.286 & 0.313 & 1.638 & 0.328 \\
\hline lokasi & 0.33 & 0.214 & 0.124 & 0.286 & 0.188 & 1.141 & 0.228 \\
\hline fasilitas & 0.165 & 0.429 & 0.248 & 0.286 & 0.313 & 1.44 & 0.288 \\
\hline luas & 0.11 & 0.071 & 0.083 & 0.095 & 0.125 & 0.484 & 0.097 \\
\hline desain & 0.066 & 0.071 & 0.05 & 0.048 & 0.063 & 0.297 & 0.059 \\
\hline jumlah & 1 & 1 & 1 & 1 & 1 & 5 & 1 \\
\hline
\end{tabular}

Tabel 3 Perhitungan Niai $\lambda$ untuk Perhitungan Uji Konsistesnsi

\begin{tabular}{|l|c|c|l|l|l|l|l|c|}
\hline & harga & lokasi & $\begin{array}{l}\text { Fasili } \\
\text { Tas }\end{array}$ & \multicolumn{1}{c|}{ Luas } & \multicolumn{1}{c|}{ desain } & jml & bobot & $\lambda$ \\
\hline Harga & 0.328 & 0.228 & 0.576 & 0.29 & 0.297 & 1.719 & 0.328 & 5.247 \\
\hline Lokasi & 0.328 & 0.228 & 0.144 & 0.29 & 0.178 & 1.168 & 0.228 & 5.119 \\
\hline Fasilitas & 0.164 & 0.456 & 0.288 & 0.29 & 0.297 & 1.496 & 0.288 & 5.194 \\
\hline Luas & 0.109 & 0.076 & 0.096 & 0.097 & 0.119 & 0.497 & 0.097 & 5.13 \\
\hline Desain & 0.066 & 0.076 & 0.058 & 0.048 & 0.059 & 0.307 & 0.059 & 5.167 \\
\hline Jumlah & 0.994 & 1.065 & 1.161 & 1.016 & 0.95 & 5.187 & 1 & 25.86 \\
\hline
\end{tabular}

Menghitung prioritas rating dengan cara membandingkan nilai rating dengan total nilai rating. Untuk menghitung prioritas ideal, normalisasi dengan cara membagi setiap prioritas dengan nilai tertinggi dari setiap prioritas.

$$
\begin{gathered}
\lambda \max =\frac{\text { total }}{\text { jumlah kriteria }}=\frac{25.86}{5}=5.1716 \\
C I=\frac{\lambda m a k s-n}{n-1}=\frac{5,1716-5}{5-1}=\frac{0,1716}{4}=0,0429 \\
C R=\frac{C I}{R I} \\
=\frac{0,0429}{1,12}=0,038
\end{gathered}
$$

Karena nilai consistensi ratio $<0,10$ : jadi kriteria penilaian konsisten dan dapat diteriama (acceptable). 
Tabel 4 Perhitungan Bobot Setiap Rumah

\begin{tabular}{|c|c|c|c|c|c|c|}
\hline \multirow{2}{*}{$\begin{array}{c}\text { Ruma } \\
\mathrm{h}\end{array}$} & \multicolumn{5}{|c|}{ Kriteria } & \multirow{2}{*}{ Bobot } \\
\cline { 2 - 6 } & Harga & Lokasi & $\begin{array}{c}\text { Fasilita } \\
\mathrm{s}\end{array}$ & $\begin{array}{c}\text { Luas } \\
\text { Tanah }\end{array}$ & Desain & \\
\hline $\begin{array}{c}\text { Ruma } \\
\text { h-1 }\end{array}$ & 0.9999 & 0.4490 & 0.8542 & 0.1911 & 0.1175 & $\begin{array}{c}2.621101 \\
74\end{array}$ \\
\hline Ruma & 0.3333 & 91 & 13 & 49 & 57 & 74 \\
h-2 & 03 & 91 & 13 & 49 & 57 & 51 \\
\hline Ruma & 0.6660 & 0.6736 & 0.5761 & 0.1911 & 0.1175 & 2.224545 \\
h-9 & 61 & 36 & 42 & 49 & 57 & 45 \\
\hline
\end{tabular}

Sedangkan langkah perhitungan di dalam fuzzy Mamdani adalah 1) membuat fungsi keanggotaa pada setiap kriteria dan output, 2) membuat rule dengan notasi and, 3) menghitung menggunakan inferensi minimum mamdani. Proses perhitungan dengan Fuzzy Mamdani menggunakan tool Matlab pada langkah 1, 2, dan 3 dijelaskan pada gambar 3, 4, dan 5 berikut ini:

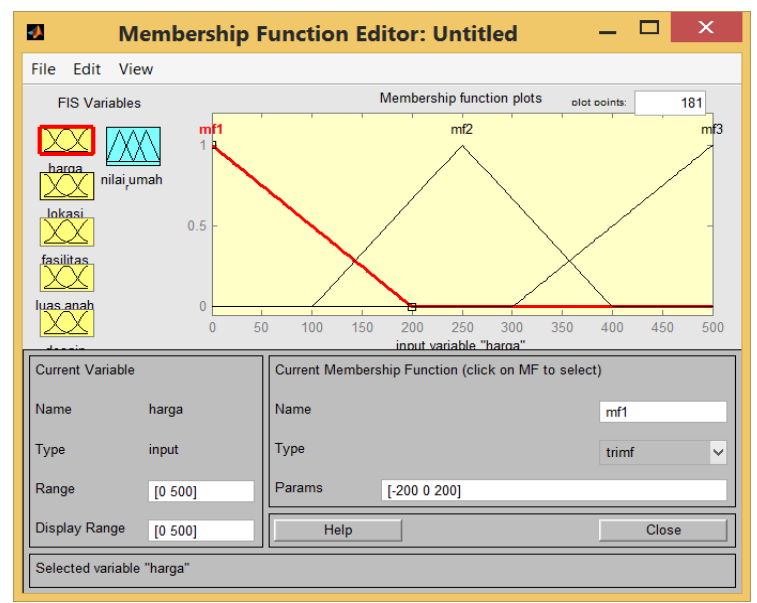

Gambar 3 Membership function (fungsi keanggotaan) setiap kriteria penilaian rumah

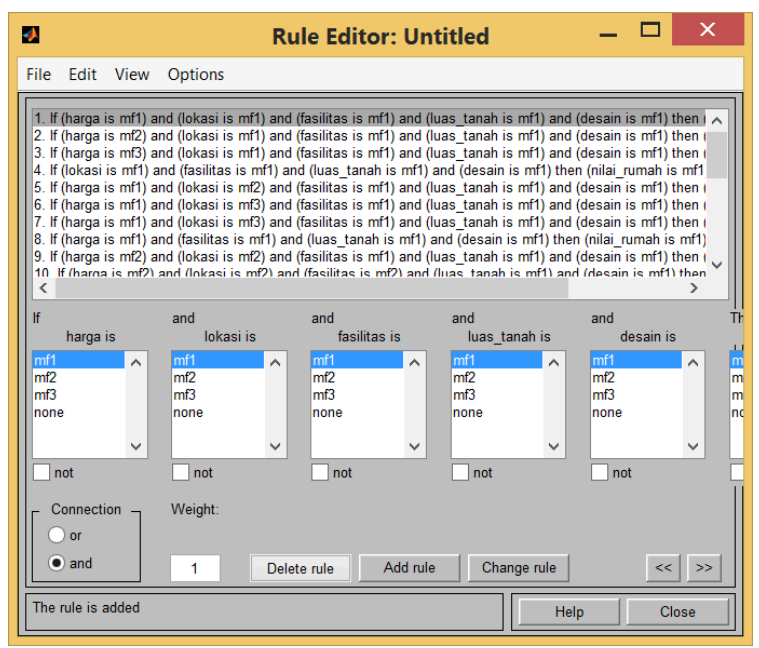

Gambar 4 Membuat rule dengan notasi AND

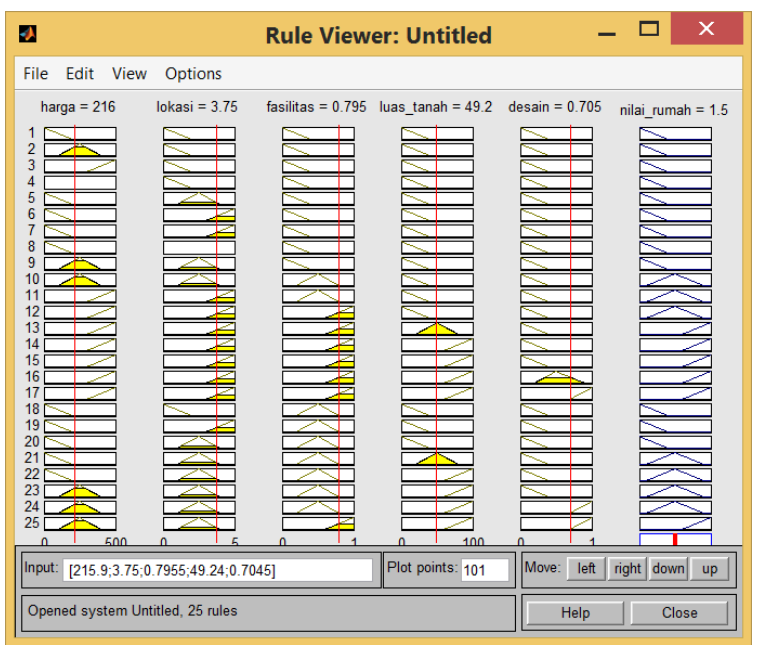

Gambar 5 Menghitung hasil penilaian alternative rumah dengan inferensi Mamdani

$D$. Pengujian dan analisa hasil.

Perhitungan AHP dan fuzzy mamdani dicoba pada beberapa alternatif rumah (dalam penelitian ini ada 9 alternatif pilihan rumah) dan dihitung menggunakan kedua metode tersebut. Hasil perhitungan menggunakan metode AHP dan menggunakan fuzzy mamdani kemudian dibandingkan, mana diantara kedua metode tersebut yang mempunyai nilaai error lebih sedikit.

\section{HASIL}

Pada bagian ini menjelaskan hasil dari penilaian rumah menggunakan AHP dan Fuzzy Mamdani. Hasil dari penilaian menggunakan metode AHP dapat dijelaskan menggunakan tabel berikut:

Tabel 5 Hasil Penilaian Rumah Menggunakan AHP

\begin{tabular}{|r|l|c|}
\hline No & Nama rumah & nilai rumah \\
\hline 1 & IR 39 & 2.615518572 \\
\hline 2 & IR 46 & 1.960303333 \\
\hline 3 & GZZ 38/78 & 2.843746027 \\
\hline 4 & GZZ 45/91 & 2.516138407 \\
\hline 5 & GZZ 60/98 & 2.344784761 \\
\hline 6 & GM 50/105 & 2.325067735 \\
\hline 7 & M 36/60 & 2.399581101 \\
\hline 8 & M 39/84 & 2.496421382 \\
\hline 9 & M 49/105 & 2.228227454 \\
\hline
\end{tabular}

Hasil penilaian rumah menggunakan Fuzzy Mamdani dijelaskan pada tabel berikut ini: 
Tabel 6. Hasil penilaian rumah menggunakan Fuzzy Mamdani

\begin{tabular}{|r|l|c|}
\hline No & Nama rumah & nilai rumah \\
\hline 1 & IR 39 & 2.17 \\
\hline 2 & IR 46 & 1.52 \\
\hline 3 & GZZ 38/78 & 2.35 \\
\hline 4 & GZZ 45/91 & 2.24 \\
\hline 5 & GZZ 60/98 & 1.76 \\
\hline 6 & GM 50/105 & 1.98 \\
\hline 7 & M 36/60 & 2.21 \\
\hline 8 & M 39/84 & 2.84 \\
\hline 9 & M 49/105 & 2.55 \\
\hline
\end{tabular}

Dari hasil penilaian menggunakan metode AHP dan Fuzzy Mamdani dapat dibandingkan menggunakan grafik seperti pada gambar berikut.

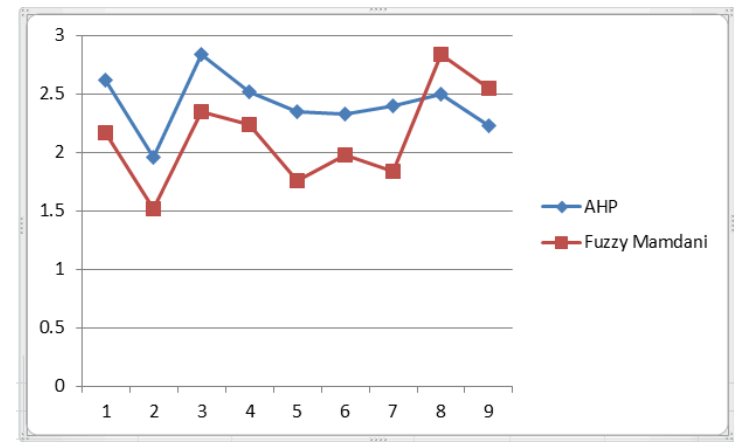

Gambar 6 Grafik Perbandiangan AHP dan Fuzzy Mamdani untuk Penilaia Rumah

Dari perbandiangan hasil penilaian dengan menggunakan metode AHP dan Fuzzy Mamdani didapatkan hasil perbandingan $1: 0,90298$.

Nilai MSE untuk hasil penilaian dengan metode AHP adalah 0.048538. Sedangkan untuk hasil penilaian dengan metode Fuzzy Mamdani diperoleh nilai MSE sebesar 0.082822. Jadi bisa ditarik kesimpulan bahwa penilaian rumah untuk sistem pendukung keputusan dalam pemilihan rumah menggunakan AHP lebih akurat dari pada menggunakan fuzzy mamdani dikarenakan nilai MSE (Mean Square Error) dari metode AHP lebih kecil dibandingkan Fuzzy Mamdani.

\section{KESIMPULAN}

Berdasarkan hasil pembahasan penelitian ini, maka dapat diambil kesimpulan sebagai berikut:

1. AHP dan Fuzzy Mamdani dapat dijadikan sebagai analisis dalam sistem pendukung keputusan menentukan pilihan rumah.

2. Dari perbandiangan hasil penilaian dengan menggunakan metode AHP dan Fuzzy Mamdani didapatkan hasil perbandingan $1: 0,90298$

3. Penilaian rumah untuk sistem pendukung keputusan dalam pemilihan rumah menggunakan AHP lebih akurat dibandingkan dengan menggunakan fuzzy mamdani, dikarenakan nilai MSE (Mean Square Error) dari metode AHP lebih kecil dibandingkan Fuzzy Mamdani dengan nilai MSE AHP sebesar 0.048538 .

\section{DAFTAR PUSTAKA}

[1] E. Widiastuti and S. Handayani, PROSIDING SEMINAR NASIONAL STATISTIKA, 10th ed. semarang: Universitas DIPONEGORO, 2013.

[2] T. Fitriani, "Implementasi Sistem Pendukung Keputusan Penilaian Kinerja Pegawai Negeri Sipil dengan Model Fuzzy Multi Atribute Decision Making," 2016.

[3] A. F. Nurifai, N. Rijati, and S. M. Kom, "Sistem Pendukung Keputusan Pemilihan Perumahan Dengan Metode Fuzzy Tahani ( Studi Pada Pt . Bukit Semarang Jaya Metro )," no. 3.

[4] W. Sudirman, "ciri-ciri Sistem Pendukung Keputusan," 2008.

[5] S. MARDIYATI, JULIANA, and D. DRIYANI, "Sistem Penunjang Keputusan Pemilihan Program Studi," 2013.

[6] A. Suwandi, "PENGAMBILAN KEPUTUSAN PEMILIHAN PERUMAHAN MENENGAH DAN SEDERHANA DI KABUPATEN SUMENEP DENGAN ANALYTICAL HIERARCHY PROCESS," EXTRAPOLASI J. Tek. Sipil, vol. 8, no. 2, Dec. 2015.

[7] A. Y. Ranius, "Sistem Penunjang Keputusan Penetapan Dosen Pembimbing dan Penguji Skipsi Dengan Menggunakan Metode AHP," 2013. 